Locked Out: Generational inequalities of housing tenure and housing type

\begin{tabular}{|r|l|}
\hline Journal: & Property Management \\
\hline Manuscript ID & PM-09-2021-0067 \\
\hline Manuscript Type: & Research Paper \\
\hline Keywords: & $\begin{array}{l}\text { Ageing, Housing, Policy Influence, Private rental, Australia, Generational } \\
\text { inequalities }\end{array}$ \\
\hline
\end{tabular}

SCHOLARONE ${ }^{\text {IM }}$

Manuscripts 


\section{Locked-Out: Generational Inequalities of Housing Tenure and Housing Type Introduction}

The increasing difficulties in young adults accessing the housing market has been observed across many countries with authors such as McKee (2012) and Beer et al. (2011b) articulating that this cohort is increasingly locked-out of the housing market with a growing number delaying homeownership mainly because of exponential increases in property prices. As a consequence of market inefficiency, many young people are frequently compelled to revert to the parental home or the rental market (Bessant and Johnson, 2013). Whilst, at the upper end of the age spectrum there is the challenge of aging populations, with the projected share of the world's population above the age of 65 years estimated at $16 \%$ by 2050 (Population Reference Bureau, 2018).

Demographic change imposes major costs on governments and while their focus has been mainly on health and social care of ageing populations, lesser emphasis has been given to the standard of living and inequalities in housing prospects (Searle and McCollum, 2014). In connecting age and tenure, the demographic shift places the spotlight on the differential housing tenure choice that has developed. In this context, Reed (2016), in reflecting upon segmentation of housing between different age brackets, argues that an older population, mainly because of their wealth accumulated, can afford homeownership in areas with higher property values and that the wider effect of this cohort on the housing market should not be underestimated.

The use of tenure as a point of analysis and discussion in housing research is well established particularly with regards to the opportunities of housing wealth gain from the ownership of housing and the possibility to make capital gains and extract economic rents. What is less 
known is how this housing tenure question relates to age demographics and how this varies over time and space. This question of tenure and generational change is therefore important as to confirming or providing nuance as to whether younger generations are in some advanced economies becoming renters and thus diminishing the equality opportunity and choice to make gains from owner-occupation. Furthermore, this tenure inequality may conflict with policy intentions of trying to increase owner-occupation for the majority and encouraging first timebuyers.

Australia has a growing housing market that promotes owner occupation tenure. This 'property-owning democracy' was described over four decades ago by Kemeny (1977) as being the most powerful ideology in Australian social and political life. However, Australia is a liberal welfare regime with an entrenched ideology of homeownership. Unfortunately, this ideology has become a 'false promise' (Arundel and Ronald, 2020) as the cities in which most of the population live demonstrate the stark housing problem of those who are not homeowners combined with an ageing population with whom the larger share of housing wealth is held. Considering these sharply defined generational issues, the aim of this paper is to analyse how housing tenure and differences in housing type vary on a generational basis across Australia.

The projected share of Australia's population above the age of 65 and over will increase from its current level of $15 \%$ to $21 \%$ by 2054 (AIHW, 2017). The selection of Australia for this study is based on this rapidly ageing population, in accordance with other western countries, and the pressures that this place on housing and wider policy issues concerning taxation and inherited wealth (Stebbing and Spies-Butcher, 2016). Comparisons are made across intergenerational groups to establish how the distribution of housing tenure is changing and how similar or different these changes are between generational groups. By studying 
generational differences, the paper builds upon previous research by Stebbing and SpiesButcher (2016) which, using tenure trends up to 2012, observed that homeownership rates have continued to decline in Australia for all age groups under 65 years with the largest decline in the younger age groups. They noted that homeownership rates for 35-44-year-olds had fallen from $73 \%$ in $1994 / 1995$ to $62 \%$ in $2011 / 2012$ and for the $25-34$ age group from $54 \%$ to $42 \%$ over the same period. With the effects of changing demographics and ageing populations seemingly influencing housing tenure and its intergenerational distribution, the focus of this study is timely in exploring changes in housing distribution in Australia.

Given this context, the research questions at the centre of this study are first whether Australia and the main metropolitan areas demonstrate significant differences in tenure and property type between generational groups? Second whether those considered to be the millennial generation are more likely to rent rather than own and implications on property type? Third, whether such variation in tenure and property type by millennials is one of individual choice and lifestyle or the impact of housing market inefficiencies? Underpinning these questions are wider issues of spatial disadvantage and the concerns for spatial justice (Soja, 2010) as the patterning of housing ownership can make equity and housing choice more challenging.

To explore in greater detail these issues, the paper focuses on an in-depth case of the city of Adelaide, the state capital of South Australia. The Adelaide case study demonstrates the path dependent and contextual consideration of changing age demographics and the housing stock in terms of spatial distribution of tenure. As reflected by Kemeny (1977), Adelaide has traditionally been a city of immigration reception with many of these cohorts now retiring. Hence there is a housing spatial tenure distribution that locates many of the current old generations in larger owned parcels in the inner suburbs, whilst there is an emerging younger 
generation renting in the outer suburbs. Given this context, the paper focuses on generational differences in housing tenure and type raising issues of equity in terms of the spatial distribution of housing wealth in different generations and equality of tenure choice for different generations.

The paper is structured as follows. Section two is a literature review reflecting on theory and how intergenerational and generational issues impact on housing. Section three considers the housing market structure in Australia, the effects of housing distribution on housing tenure and the generational differences associated with these changes. Section four discusses the methodology employed in terms of the data sets and key variables. Section five discusses the results and findings focussing on the similarities and differences across Australia and explores the case of Adelaide to further illustrate issues regarding how locked-out properties impact on the housing market and generational-tenure effects. Section six provides a wider discussion of issues and Section seven draws conclusions and policy implications.

\section{Literature review: Intergenerational and generational housing in tenure and type}

The broad theory of inter-generational transfer of housing wealth has a long pedigree in the literature for example Mannheim's (1952) work on generation concepts and social stratification. Bourdieu (1990), in building on Mannheim's work, argues for a 'habitus' in generations, a set of characteristics that is used to explain perceptions including historical, social and individual characteristics. Likewise, Hoolachan and McKee (2019, p213) draw upon Mannheim to set a contextual basis arguing that Mannheim's theory "was attentive to heterogeneities within a generation, as well as inter-generational differences". Such differences are often associated with changing housing aspirations over time and life-course events (Beer et al., 2011b; Crawford and McKee, 2018; Lowies et al., 2019; Preece et al., 2020) and the 
potential for intergenerational resource transfer (Lux et al., 2018). As an example of this Köppe (2018) observes how those young adults who live with parents for longer are more able to purchase a home more quickly than those renting, while an earlier study of life-chances in the housing market by Payne and Payne (1977) found that housing status pathways are reinforced by social conditions and socially structured inequalities.

Morrow-Jones and Wenning (2005), in their research of housing life cycle and housing lifecourse, argue that greater considerations should be given to major life events such as the age at the point of first homeownership, income, presence of children, marital status, and duration of ownership. Similarly, Helderman and Mulder (2007) articulate that inter-generational transmission of wealth via gifts to offspring for homeownership are based on socialisation from parent to child. For Druta and Ronald (2017) the provision of parent-child gifts reaffirms moral control over the relationship and thus normalising the idea of a particular tenure choice.

Wealth transmission is further explored by Mulder and Smits (2013) who find that parental homeownership had an impact on child homeownership wealth support, similarly Albertini et al. (2018) argue that the wealth support to enable homeownership is reinforced by the experience of the parent being similarly supported by their parents to purchase a home. For Hui et al. (2016), inter-generational wealth transfer must also consider fertility effects, given evidence that there is a correlation of low fertility rates and rising house prices. Hirayama and Ronald (2008) stress that even with intergenerational wealth transfer, the ability of more recent generations to access homeownership has become increasingly difficult.

The type of housing tends to manifest in a particular housing tenure and adds to the perception inequality in the housing market. In this context, Bramley and Power (2009) provide a 
theoretical basis with regards to housing type arguing that urban form itself plays a part in equality of outcome. Soja (2010) considers that linkages between housing type and housing tenure adds to wider spatial justice concerns despite taxonomical limitations, with generations in particular locations experiencing long-term widening inequities depending on tenure and type of housing. Likewise, Murie (1991) articulates that homogenous categories of tenure can be unhelpful given the nuances in the relationship between housing and social change.

In the context of social change, Arundel and Doling (2017) argue that asset-based welfare through housing wealth accumulation as equity is unequal, and that equity in housing is becoming increasingly difficult to access for younger cohorts with implications for wider society. From a political economy perspective, Fuller et al. (2020) see the rise in wealth-toincome ratios driven by rising house prices and other financial assets, rather than a tenured 'choice' of homeownership. Christophers and O'Sullivan (2019) argue that the shift towards homeownership (in Sweden) depends on both parental tenure status and place of birth while Christophers (2019) makes a compelling case that rental tenure and its relation to owneroccupation is of paramount interest for future policy in addressing housing asset wealth inequalities. As such, significant changes in long-term tenure trends aligns with the equality of opportunity to move through tenures and is becoming less of a 'choice' for entire generations.

Galster and Wessel (2019) emphasise that social inequalities in housing wealth (in Norway) can be transmitted across multiple generations, with grandparents having an influence on housing wealth. In more hard, economic terms (in China), Hui et al. (2020) find that wealth is transmitted intergenerationally from parents to offspring (often male) incentivising greater private ownership. Arundel and Hochstenbach (2019) recognise that spatial inequalities and the spatial polarisation of access to housing wealth is differentiated (in the Netherlands) by 
drivers of income, employment, and parental wealth. Hoolachan and McKee (2019), focussing on the Baby Boomers and Millennial generations (in the UK), articulate that a lack of government representation (and subsequent policy issue), rather than resentfulness towards an older generation, is a major influential factor that leads to inter-generational disparity.

This paper, in drawing upon the literature, considers generational differences in housing tenure and type in the context of spatial polarity in housing wealth and affordability issues relating to both ownership and rent, aligned with broader theoretical spatial justice concerns (Soja, 2010). The consensus from the literature is that intergenerational housing wealth based on tenure is well ingrained in social structures. Hence research that captures generational 'snapshots' and highlights how lag in the housing market impacts upon generational tenure and housing choice makes an important contribution.

\section{Housing market structure in Australia: generational tenures}

Stebbing and Spies-Butcher (2016) suggest that trends in homeownership have been intensifying inequalities across society in Australia and indeed earlier work by Arthurson (2008) considers that equalities reflect socio-economic mixing of public housing estates that have become concentrated areas of disadvantage. Whilst O'Dwyer (2001) demonstrates that inheritance wealth is not necessarily having a distributional effect to society; Cigdem and Whelan (2017) argue differently that intergenerational transfers play an important role in facilitating homeownership. Furthermore, Saunders and Siminski (2005) articulate that the money forgone by renting rather than owning property also accounts for a proportion of housing wealth inequality that is mainly felt by lower income groups. 
A report by the Australian Housing and Urban Research Institute (AHURI, 2019) on subsidies such as the Commonwealth Rent Assistance programme highlights further the rising issue of young people experiencing housing affordability stress. Interestingly, an earlier AHURI report by Barrett et al. (2015) argues that the transition to owner occupation is experienced by older groups and less so by lower-income groups. Also, policy reports such as those by the Committee for Economic Development of Australia (CEDA) provide interesting housing data and a narrative regarding the intergenerational consequences of high housing costs and falling homeownership (CEDA, 2017).

Morris (2009) highlights that Australian housing policy has largely focussed on facilitating homeownership and providing emergency needs, thus leaving an increasing number of older residents that have not attained owner-occupation being in a situation of housing stress with untenable housing costs and minimal disposable income. For Beer et al. (2011a), housing policy in Australia is seen via a lens of specific housing assistance, they argue that, the outcomes of applying such policy are received equally in terms of wellbeing and material economic benefit.

However, Gurran and Phibbs (2015) see Australian housing policy as inherently politically and institutionally biased in favour of retaining the status quo of rising house prices to benefit capital gains, rather than dealing with the root causes of housing affordability. An example being the tax break incentive to owning a second (or more) property, in that any property investment losses can be offset against income. Such direction of housing policy has increasingly not favoured low-income renters with Yates (2016) calling for a radical institutional solution such as financing for the low-income rental sector. However, according to Beer et al. (2016) restrictions in welfare and income regimes have further disadvantaged the 


\section{Methodology}

This paper uses a comparative research design, an approach used widely in the field of housing. For example, Leishman et al. (2013) used comparative analysis to explain multilevel models and its predictability of housing sub-markets while Pickvance (2001) concluded that urban and housing studies are ideal for comparative research. In this paper, the comparative method is manifest through two dimensions; first, in considering housing tenure and housing type distributions across generations and second, through cross-city analysis.

Secondary data notably the Australian Bureau of Statistics (ABS) Census of Population and Housing for 2006, 2011 and 2016, are used to provide a comparative analysis over a 10-year horizon. Analysis is conducted using ABS Tablebuilder with data amalgamated for the whole of Australia and by Greater Capital City Statistical Areas (GCCSA) or at ABS postcode level (POA). The GCCSA segments Australia into the eight state and territory capital cities plus regions representing the rest of each state/territory. The capital city areas are broader than the build-up areas around cities as they intend to include townships and rural areas surrounding the cities. For the analysis contained in this paper, the population is split into generational groups as comparison units with the following generational definitions and labels used (Dries, et al. 2008), according to period of birth:

1925 - 1945: The Silent Generation

1946 - 1964: Baby Boomers 


\section{5 - 1980: Generation X \\ 1981 - 2001: Millennials}

Comparison of generational differences in this paper, as discussed, is a snapshot with each generation being compared at specific points in time, whereas dynamic changes of generational tenure change sits with a life-cycle approach and would require a multitude of circumstantial and contextual changes over time. Across the three census periods the analysis "follows" these generations by selecting appropriate age groups at each census. This means that while the older generational groups remain relatively fixed, the Millennials group increases significantly from 2006 to 2016 as more of this generation become independent adults. The data reflects individual participants rather than households or dwellings and captures all independent adults that are not visitors to Australia on census night. The research undertaken for this paper focuses specifically on two key housing characteristics namely tenure and property type for the state/territory capital cities of Australia.

Concerning housing tenure, persons living in a property that is owned outright or owned with a mortgage are grouped together and all forms of rental are grouped together regardless of landlord. These are calculated as a proportion of all people within that generation group, excluding responses where the tenure is not stated or not applicable. Similarly, for housing type, the proportion of people living in dwellings in semi-detached, row or terraced or townhouses; separate houses or detached houses; flats or apartments, are calculated as a proportion of all people within that generation group, excluding responses where the housing type is not stated. The analysis focuses initially a country-wide, Australia level and then secondly at a city level. 
A third level of analysis utilises one of the capital cities, Adelaide, as a case study to explore how locked-out properties, namely those that do not transact over a long period of time, in this case 33 years, characterises problems of inter-generational choice in the housing market. Using the Valuation List through the Office of the Valuer-General South Australia, the latest sale date for every domestic property in the metropolitan area, defined as within the Adelaide's urban growth area, was obtained. The Valuation List uses data from the Lands Titles Office and records the latest transaction data and price for every property. These data have been held on computer file since 1970 but in 1984 the system was updated, modified and additional data added making this the earliest year used in this analysis. A change to the title occurs if the land is transferred (even if for no-consideration such as in a bequest or family arrangement) or there is a change to the land such a subdivision.

For this analysis, the case study is based on all privately held residential properties in Adelaide and with the key variable being the last time that the property changed hands with all sales of property recorded in a separate sale history file. The 2017 Valuation List was used, providing temporal synergy to the 2016 census, and enabling analysis over a period from 1984 to 2017 . The valuation list defines properties under land uses. For this research, all privately owned residential properties are broken down into houses (detached and semi-detached), home units (including individually titled apartments and townhouses with common property), vacant land, rural residential and rural living allotments and other residential properties. Properties owned by various levels of Government and companies are excluded. 


\section{Results and findings}

As discussed in the methodology, the analytics in this paper focus on two key characteristics housing tenure and housing type, exploring how these vary by the four generational groups across three time periods $(2006,2011,2016)$. The analysis is undertaken first at Australia country-wide level and then second at a city level for the 8 state/territory capital cities of Australia (Sydney, Melbourne, Brisbane, Perth, Adelaide, Canberra (the federal capital), Hobart and Darwin). The third tier of this analysis is a more detailed exploration of Adelaide that assesses the extent to which younger generations can be locked-out of access to certain housing markets and locations.

\section{Generational Variation - Australia wide picture}

In relation to tenure, the analysis focuses upon variations between the owner-occupied sector (either owned outright or with a mortgage) and the private rented sector. For Australia as a whole, striking differences are apparent on an intergenerational basis with homeownership clearly the dominant tenure for the Silent Generation and the Baby Boomers, more than $80 \%$ for the former and circa $80 \%$ for the latter (Figure 1). Furthermore, patterns have remained consistent over the three time periods emphasising the security that homeownership provides for older-households and also representing cumulated wealth in many circumstances over several decades of work. Generation X shares many of the same characteristics in terms of tenure type with ownership again dominant but at a lower level, circa $65 \%$ to $70 \%$ of households, over the three census periods though highest in the last of these. Interestingly, on an annual basis over the period 2006-2016, Generation X has the highest rate of increase in homeownership ( $0.88 \%$ annually), compared to an annual increase of $0.11 \%$ for Baby Boomers and a small annual rate of decline for the Silent Generation $(0.1 \%)$. This pattern highlights the 
increasing and broadly predictable trend to home ownership as those in Generation X start to age.

\section{$<$ Insert Figure 1 here $>$}

In contrast, Millennials display a significant shift in tenure with rental being of equal importance to homeownership in the 2016 census. This dynamic arguably contextualises problems of affordability and the ability to access the housing market, principal of which are the large deposits required. The findings may also capture a growing trend, similar to that observed by Sissons and Houston (2019) in the UK whereby this generation is placing less emphasis on the importance of owning a house for the greater flexibilities offered by renting. The reducing importance of homeownership for Millennials is apparent in a $0.34 \%$ annual decline over the census periods.

Differences across the four generations by dwelling type are less apparent (Figure 1) with detached housing types being dominant for each generation, highest for the Baby Boomers and least dominant for Millennials, though accounting for $57 \%$ of the latter in 2016 . For Millennials semi-detached/row/townhouses (19\%) and apartments (22\%) are taking an increasing market share at a faster rate than for the other generational groups as investment activity becomes increasingly focused on these housing types, notably apartments.

\section{Generational Variation by city}

Tenure differences apparent at the macro-Australia wide level are broadly reflected at the city level of analysis (Figure 2). Specifically, the overall pattern of homeownership dominating for both the Silent Generation and Baby Boomers, less dominant but still the main tenure for 
Generation $\mathrm{X}$ and the rise of the rental sector for Millennials is observable across the cities. However, certain nuances and important differences are apparent on a comparative basis across the eight capital cities.

\section{$<$ Insert Figure 2 here $>$}

Cities that most closely follow the traditional model of the primacy of home ownership are Adelaide and Perth, the state capitals of South Australia and Western Australia respectively, both large states geographically and with one dominant metro area. For these cities the dominance of homeownership is apparent across three generations (the Silent Generation, Baby Boomers and Generation X) and still the modal tenure for Millennials, though rental accommodation takes a market share approaching that of the ownership sector (in $201644.7 \%$ rental for Millennials in Adelaide and 41.6\% in Perth). Hobart, the capital of Tasmania, the only offshore state in Australia, has a similar tenure pattern but departs somewhat from Adelaide and Perth with regards to the high level of renting in the Millennial generation $(47.3 \%$ in 2016), a trend not apparent in Generation X.

The two major cities in Australia, Melbourne and Sydney, adhere to the pattern of dominance of homeownership in two generations (the Silent Generation and Baby Boomers) with Generation X showing higher levels of rental in Sydney (32.3\% in 2016) and Melbourne (26.8\% in 2016). Interesting for both cities though is that the percentage of Generation $\mathrm{X}$ renting declines by circa 5\% to 6\% between 2006 and 2016 suggesting a tenure dynamic in this group towards greater homeownership with age. In contrast, the results show that rental accommodation for Millennials in both cities is on an increasing projection between 2006 and 2016 and close to that of homeownership rates. Indeed, for Sydney in 2016 renting becomes 
the modal tenure for Millennials, $51.2 \%$ of households up from 45.2\% in 2006. In Melbourne, a similar pattern is apparent with $48.7 \%$ of Millennials renting in 2016 up from $43.5 \%$ in 2006 .

Three cities (Brisbane, Canberra and Darwin) show a clear departure from the macro-Australia picture in having rental as the dominant tenure for Millennials. This pattern is most apparent for Darwin with rental exceeding homeownership as the main tenure in each of the three census periods, reaching $61.8 \%$ for Millennials in the 2016 census inferring that rental is firmly established as a rental choice and not a recent phenomenon. Rental, although not the dominant tenure, also takes a high share for Generation X in Darwin with $40.3 \%$ of households declining from $43.6 \%$ in the 2006. In both Brisbane and Canberra, whilst less pronounced, rental exceeds homeownership as the primary tenure for Millennials across the three census periods, $53.6 \%$ for Brisbane and 50.8\% for Canberra respectively. Both these cities also highlight the move of Generation X householders away from rental in Brisbane declining from 36.1\% in 2006 to 31.4\% in 2016 and even more marked in Canberra with rental for Generation X reducing from $35.6 \%$ to $27.5 \%$.

Variation in housing type at city level displays less variability with detached houses consistently dominant across all three census periods (Figure 3). The city showing any degree of deviation from this pattern, Sydney, is characterised by significant growth of apartments. Reflecting the greater availability of supply, 37.4\% of Millennials in 2016 are living in apartment properties in Sydney up from $27.6 \%$ in 2006. This trend towards apartment developments is linked to city living and correlates with tenure changes discussed. In this context, Sydney has been the focus of investment activity, often driven by cross-border capital market flows, a trend that is less apparent in Melbourne where circa 20\% of Millennials choose apartment living, a figure that is relatively constant over the three census periods $(21.2 \%$, 
$22.1 \%, 21.7 \%$ respectively) and possibly reflecting less interest by international investment interest in Melbourne compared to Sydney. Darwin also is interesting in this context, where the greater focus on rental accommodation is again reflected in a growing apartment sector, increasing from $23.1 \%$ in 2006 , to $24.9 \%$ in 2011 and $28.0 \%$ in 2016.

\section{$<$ Insert Figure 3 here $>$ \\ Adelaide case study: locked-out analysis}

The previous analysis has articulated the high levels of homeownership notably by the Silent Generation and Baby Boomers and significantly lower rates for Millennials. One underresearched consequence of this differential level of ownership is the potential for properties to be locked-out of the market. In exploring this further, Adelaide, which as shown characterises well the tenure structures in Australia, is used to examine the proportion of properties that fit into this locked-out category, their characteristics and location within the city. Furthermore, the extent to which this phenomenon is being resolved through the normal market mechanisms is assessed.

Table 1 presents evidence by current land use category, as defined by the Office of the ValuerGeneral South Australia, and when last sold, banded in years ${ }^{1}$. Of the privately-owned residential properties in Adelaide, $78.2 \%$ are houses and 17.3\% units (mainly apartments), with small proportions of other residential uses. Of the small amount classified as vacant land $(1.1 \%$ in total), most sold in the last 5 years. Units are held for shorter time periods with $35.8 \%$ having sold in the last 5 years and only $13.8 \%$ held for greater than 20 years. By comparison $27.7 \%$ of houses sold over the last 5 years and, more significantly in terms of this analysis, $14.8 \%$ of

\footnotetext{
${ }^{1}$ As discussed in the methodology section, the data covers the period from 1984 to 2017
} 
houses have not sold in the period from 1984-2017 (a period of 33 years). Importantly, as sales of houses represent opportunities for redevelopment and increasing housing density, the analysis focuses on this housing type.

\section{$<$ Insert Table 1 here $>$}

The analysis of sales shows that those properties held for longer periods are typically on larger sites, are smaller in size and older buildings. Older sites with smaller run-down houses represent an opportunity for redevelopment or densification resulting in the sale of new houses (or units) on smaller sites. Many of the properties held for longer periods have high site values and relatively lower capital values resulting in a situation where the capital value $(\mathrm{CV})$ is effectively site (land) value (SV). The lower the ratio of CV to SV and the closer to 1 , the greater the likelihood that properties are likely suitable for redevelopment. The analysis for Adelaide (Figure 4) shows the median CV to SV ratio to be typically 1.6 and above across house sales over the last 15 years but lower and starting to approach 1 for properties held for more than 33 years inferring their redevelopment potential. Furthermore, the difference in the site areas between all houses and those long held in this analysis (over 33 years) is appreciable (Figure 4). Specifically, for larger plot sizes over $550 \mathrm{~m}^{2}$, long-held houses, are dominant reinforcing the lock-out argument and exclusion from the market of substantial sites with major development potential.

$<$ Insert Figure 4 here $>$ 


\section{Discussion}

This paper highlights the growing importance of generational inequalities in housing tenure and type and has sought to disentangle some of the complexities and inequalities within the Australian housing market identified by previous authors that have suggested declining homeownership and rising rental in the private sector. However, there has been less clarity as to how these are manifest and indeed impact across generations and spatially across metro areas.

The results presented in this paper show that while homeownership is still the dominant tenure type in Australia, the evidence from the 2016 census is that overall, it is continuing to decline (Figure 1). However, a key finding from this study is the variation across the generation groups with the analysis showing homeownership at consistent and high levels across both the Silent Generation and Baby Boomers and actually increasing in many circumstances for Generation $\mathrm{X}$ contrary to expectations. The latter infers that as those in Generation X start to age, the perceived greater security of homeownership and accumulated wealth become important factors in this decision-making.

The paper highlights that for Millennials homeownership is at a significantly lower level and as a tenure type is on a par with private renting and within a number of cities such as Sydney, Darwin and Canberra seemingly is becoming the primary tenure for Millennials. Thus, as articulated by Christophers (2019), inter-generational differences in housing wealth and inequality appear to be most focused on the Millennial generation. However, a key question is whether the movement towards the rental sector is driven by choice rather than affordability, with rental providing greater employment and mobility flexibility and perhaps a housing experience of greater appeal in apartment style dwelling with leisure facilities and adjacency 
to city centre entertainment supporting evidence of choosing to rent in a preferred location (Hulse and Yates, 2017).

The analysis in Figure 2 indicates that differences by housing type is less apparent across the generations due the prominence of detached housing types. Suggesting that type is of less importance than tenure in assessing housing differences on an intergenerational basis. However, within the major metropolitan areas and particularly Sydney (Figure 3), where there has been significant investment activity, including cross-border investment into apartment buildings, such units take a significant share of the housing stock across all generations and in the case of Millennials is a rapidly growing housing option, in many cases linked to renting as the 'preferred' tenure.

The analysis of residential sales in Adelaide shows how a significant portion of the house stock can get locked-out of the market as households in the Silent Generation and Baby Boomers age in place. Whilst encouraged by government policy to do so, in many instances a personal preference by householders, the analysis shows that a significant share of the housing stock that possesses considerable development potential due to its lot size is essentially excluded from the market. The paper argues that this locked-out stock and value of the housing asset (and wealth) imposes major constraints in particular on Millennials, in their locational housing choice.

The paper demonstrates that spatial polarity of housing wealth is being exacerbated on a generational basis and tenure is being spatially patterned given affordability issues aligned with broader theoretical spatial justice concerns (Soja, 2010), and arguments that housing regimes 
is deeply embedded in the wider context of welfare regimes and political relations (Kemeny, 1995).

\section{Conclusion}

In conclusion, the paper demonstrates that inequalities of housing tenure (and type) are experienced differently over generations. The importance of such inequalities is more pronounced given an ageing population that has benefited in wealth terms from a financially accessible owner-occupation tenure. For Australia at large, both the Silent Generation and Baby Boomers have benefitted greatly from the high proportion of homeownership, supported by continued policy direction over many decades.

The literature underpinning this study has focused on spatial inequality of wealth allied with tenure advantages, and less directly on the socialisation of generational change and life-chances in the housing market. Wealth transmission is also less directly considered, particularly given that this transfer may be coming more limited in enabling change to owner occupation tenure. Drawing on inequality of housing type was important for this study as was Australian case specific tenure changes that have been intensifying housing wealth inequalities and arguably misdirected housing policy dealing with low-income groups and affordability.

Analysis of variations between generations shows the stark shift of Millennials moving towards rental rather than owner occupation. This picture is the same for some of the major metropolitan cities in Australia with Sydney, Brisbane and Canberra seeing the proportion of rental tenure over-taking owner-occupation in 2016, a trend previously seen in Darwin. Concerning housing type, for 2016 Millennials take a greater percentage of apartments with increased apartment rental notably in Sydney driven by investment led development activity in this sector. 
This paper highlights how housing wealth inequalities and tenure (and type) implications are felt disproportionately and are characterised by a general shift away from owner-occupation by younger generations. Intergenerational differences in housing wealth and inequality appear to be most focused on the Millennial generation while older generations can effectively lock-out a significant share of the housing market for decades with generational impact upon location housing choice. Indeed, it is apparent that different generations are respectively unequally locked-out and locked-in to housing wealth and that a more nuanced housing/fiscal policy is required to address intergenerational differences.

\section{References}

ABS (2014), Australian historical population statistics 2014 'Table 2. Population Age-Sex Structure' (Cat no. 3105.64.001), Canberra: Australian Bureau of Statistics.

ABS (2017), Selected Personal Characteristics (Census 2016 extracted by TableBuilder), Australian Bureau of Statistics.

AHURI (2019), Why are young people receiving CRA experiencing Housing Affordability Stress? [Online] Available at: https://www.ahuri.edu.au/policy/ahuri-briefs/why-are-young-peopleon-commonwealth-rent-assistance-experiencing-housing-affordability-stress [Accessed 274 2019].

Albertini, M. Tosi, M. and Kohli, M. (2018), 'Parents' housing careers and support for adult children across Europe', Housing Studies, Vol. 33 No. 2, pp. 160-177.

Arthurson, K. (2008), 'Australian public housing and the diverse histories of social mix', Journal of Urban History, Vol. 34 No. 3, pp. 484-501. 
Arundel, R. and Doling, J. (2017), 'The end of mass homeownership? Changes in labour markets and housing tenure opportunities across Europe', Journal of Housing and the Built Environment, Vol. 32 No. 4, pp. 649-672.

Arundel, R. and Hochstenbach, C. (2019), 'Divided access and the spatial polarization of housing wealth', Urban Geography, pp. 1-27.

Arundel, R. and Ronald, R. (2020), 'The false promise of homeownership: Homeowner societies in an era of declining access and rising inequality', Urban Studies, pp. 1-21

Australian Institute of Health and Welfare (AIHW) (2017), Australia's welfare 2017, Canberra.

Barrett, G. Cigdem, M. Whelan, S. and Wood, G. (2015), The relationship between intergenerational transfers, housing and economic outcomes, Melbourne: Australian Housing and Urban Research Institute.

Beer, A. Baker, E. Wood, G. and Raftery, P. (2011a), 'Housing policy, housing assistance and the wellbeing dividend: Developing an evidence base for post-GFC economies', Housing Studies, Vol. 26 No. 7-8, pp. 1171-1192.

Beer, A. Bentley, R. Baker, E. Mason, K. Mallett, S. Kavanagh, A. and LaMontagne, T. (2016), 'Neoliberalism, economic restructuring and policy change: Precarious housing and precarious employment in Australia', Urban Studies, Vol. 53 No. 8, pp. 1542-1558.

Beer, A. Faulkner, D. Paris, C. and Clower, T. (2011b), Housing Transitions Through the Life Course: Aspirations, Needs and Policy, Bristol: The Policy Press.

Bessant, J. and Johnson, G. (2013), 'Dream on": Declining Homeownership Among Young People in Australia?', Housing, Theory and Society, Vol. 30 No. 2, pp. 177-192.

Bourdieu, P. (1990), The Logic of Practice, Cambridge: Policy Press.

Bramley, G. and Power, S. (2009), 'Urban form and social sustainability: the role of density and housing type', Environment and Planning B: Planning and Design, Vol. 36 No. 1, pp. 30-48. 
CEDA, (2017), Housing Australia, Melbourne: Committee for Economic Development of Australia.

Christophers, B. (2019), 'A tale of two inequalities: Housing-wealth inequality and tenure inequality', Environment and Planning A: Economy and Space, $0308518 X 19876946$.

Christophers, B. and O’Sullivan, D. (2019), 'Intersections of inequality in homeownership in Sweden', Housing Studies, Vol. 34 No. 6, pp. 897-924.

Cigdem, M. and Whelan, S. (2017), 'Intergenerational transfers and housing tenure - Australian evidence', International Journal of Housing Policy, Vol. 17 No. 2, pp. 227-248.

Crawford, J. and McKee, K. (2018). 'Hysteresis: understanding the housing aspirations gap', Sociology, Vol. 52 No. 1, pp. 182-197.

Dries, N. Pepermans, R. and Dekerpel, E. (2008), 'Exploring four generations' beliefs about career: Is 'satisfied' the new 'successful', Journal of Managerial Psychology, Vol. 23 No. 8, pp. 907-928.

Druta, O. and Ronald, R. (2017), 'Young Adults' Pathways into Homeownership and the Negotiation of Intra-Family Support: A Home, the Ideal Gift', Sociology, Vol. 51 No. 4, pp. 783-799.

Fuller, G.W. Johnston, A. and Regan, A. (2020), 'Housing prices and wealth inequality in Western Europe', West European Politics, Vol. 43 No. 2, pp. 297-320.

Galster, G. and Wessel, T. (2019), 'Reproduction of social inequality through housing: A threegenerational study from Norway', Social Science Research, Vol. 78, pp. 119-136.

Gurran, N. and Phibbs, P. (2015), 'Are governments really interested in fixing the housing problem? Policy capture and busy work in Australia', Housing Studies, Vol. 30 No. 5, pp. 711-729.

Helderman, A. and Mulder, C. (2007), 'Intergenerational Transmission of Homeownership: The Roles of Gifts and Continuities in Housing Market Characteristics', Urban Studies, Vol. 44 No. 2, pp. 231-247. 
Hirayama, Y. and Ronald, R. (2008), 'Baby-boomers, Baby-busters and the Lost Generation: Generational Fractures in Japan's Homeowner Society', Urban Policy and Research, Vol. 26 No. 3, pp. 325-342.

Hoolachan, J. and McKee, K. (2019), 'Inter-generational housing inequalities: 'Baby Boomers' versus the 'Millennials', Urban Studies, Vol. 56 No. 1, pp. 1-16.

Hui, E. Wang, X. and Jia, S. (2016), 'Fertility rate, inter-generation wealth transfer and housing price in China: A theoretical and empirical study based on the overlapping generation model', Habitat International, Issue 53, pp. 369-378.

Hulse, K. and Yates, J. (2017), 'A private rental sector paradox: unpacking the effects of urban restructuring on housing market dynamics', Housing Studies, Vol. 32No. 3, pp. 253-270.

Kemeny, J. (1977), 'A Political Sociology of Home Ownership in Australia', The Australian and New Zealand Journal of Sociology, Vol. 13 No. 1: pp. 47-52.

Kemeny, J. (1995), From Public Housing to the Social Market: Rental Policy Strategies in Comparative Perspective, London: Routledge.

Köppe, S. (2018), 'Passing it on: inheritance, coresidence and the influence of parental support on homeownership and housing pathways', Housing Studies, Vol. 33 No. 2, pp. 224-246.

Leishman, C. Costello, G. Rowley, S. and Watkins, C. (2013), 'The Predictive Performance of Multilevel Models of Housing Sub-markets: A Comparative Analysis', Urban Studies, Vol. 50 No. 6, pp. 1201-1220.

Lowies, B. Whait, R.B. and Lushington, K. (2019), 'Older people and home ownership: the intention to relocate', Property Management, Vol. 38 No. 1, pp. 37-51. 
Lux, M. Samec, T. Bartos, V. Sunega, P. Palguta, J. Boumová, I. and Kážmér, L. (2018), 'Who actually decides? Parental influence on the housing tenure choice of their children', Urban Studies, Vol. 55 No. 2, pp.406-426.

Mannheim, K. (1952), Essays on the Sociology of Knowledge, London: Routledge and Keegan Paul. McKee, K. (2012), 'Young People, Homeownership and Future Welfare', Housing Studies, Vol. 27 No. 6, pp. 853-862.

Morris, A. (2009), 'Contentment and suffering: the impact of Australia's housing policy and tenure on older Australians', Australian Journal of Social Issues, Vol. 44 No. 4, pp. 363-377.

Morrow-Jones, H. and Wenning, M. (2005), 'The Housing Ladder, the Housing Life-cycle and the Housing Life-course: Upward and Downward Movement among Repeat Home-buyers in a US Metropolitan Housing Market', Urban Studies, Vol. 42 No. 10, pp. 1739-1754.

Mulder, C. and Smits, A. (2013), 'Inter-generational ties, financial transfers and homeownership support', Journal of Housing and the Built Environment, Vol. 28, pp. 95-112.

Murie, A. (1991), 'Divisions of homeownership: Housing tenure and social change', Environment and Planning A, Vol. 23 No. 3, pp. 349-370.

O'Dwyer, L. A. (2001), 'The impact of housing inheritance on the distribution of wealth in Australia', Australian Journal of Political Science, Vol. 36 No. 1, pp. 83-100.

Pawson, H. Milligan, V. and Yates, J. (2020), Housing Policy in Australia, Palgrave Macmillan.

Pickvance, C. G. (2001), 'Four varieties of comparative analysis', Journal of Housing and the Built Environment, Vol. 16, pp. 7-28.

Payne, J. and Payne, G. (1977), 'Housing pathways and stratification: a study of life chances in the housing market', Journal of Social Policy, Vol. 6 No. 2, pp. 129-156. 
Population Reference Bureau (2018), World Population Data Sheet. [Online] Available at: https://www.prb.org/wp-content/uploads/2018/08/2018_WPDS.pdf [Accessed 2605 2019]

Preece, J. Crawford, J. McKee, K. Flint, J. and Robinson, D. (2020), 'Understanding changing housing aspirations: A review of the evidence', Housing Studies, Vol. 35 No. 1, pp. 87-106.

Reed, R. (2016), 'The relationship between house prices and demographic variables: An Australian case study', International Journal of Housing Markets and Analysis, Vol. 9 No. 4, pp. 520537.

Saunders, P. and Siminski, P. (2005), 'Home ownership and inequality: Imputed rent and income distribution in Australia', Economic Papers: A Journal of Applied Economics and Policy, Vol. 24 No. 4, pp. 346-367.

Searle, B. A. and McCollum, D. (2014), 'Property-based welfare and the search for generational equality', International Journal of Housing Policy, Vol. 14 No. 4, pp. 325-343.

Stebbing, A. and Spies-Butcher, B. (2016), 'The decline of a homeowning society? Asset-based welfare, retirement and intergenerational equity in Australia', Housing Studies, Vol. 31 No. 2, pp. 190-207.

Soja, E. (2010), 'Spatializing the urban, Part I’, City, Vol. 14 No. 6, pp. 629-635.

Sissons, P. and Houston, D. (2019), 'Changes in transitions from private renting to homeownership in the context of rapidly rising house prices', Housing Studies, Vol. 34 No. 1, pp. 49-65.

Yates, J. (2016), 'Why does Australia have an affordable housing problem and what can be done about it?', Australian Economic Review, Vol. 49 No. 3, pp. 328-339. 
Table 1 Sales evidence banded by years

\begin{tabular}{|l|r|r|r|r|r|r|}
\hline \multirow{2}{*}{ When Last Sold } & \multicolumn{6}{|c|}{ Current Land Use } \\
\cline { 2 - 7 } & \multicolumn{1}{|r|}{ Other } & \multicolumn{1}{c|}{ House } & \multicolumn{1}{c|}{ Unit } & \multicolumn{1}{c|}{$\begin{array}{l}\text { Rural } \\
\text { living }\end{array}$} & \multicolumn{1}{c|}{ Land } & \multicolumn{1}{c|}{ Rural } \\
\hline 1 to 5 years ago & $0.6 \%$ & $21.6 \%$ & $6.2 \%$ & $0.1 \%$ & $0.7 \%$ & $0.0 \%$ \\
6 to 10 years ago & $0.7 \%$ & $15.9 \%$ & $4.4 \%$ & $0.1 \%$ & $0.1 \%$ & $0.0 \%$ \\
11 to 15 years ago & $0.5 \%$ & $10.2 \%$ & $2.6 \%$ & $0.1 \%$ & $0.1 \%$ & $0.0 \%$ \\
16 to 20 years ago & $0.3 \%$ & $8.1 \%$ & $1.8 \%$ & $0.1 \%$ & $0.1 \%$ & $0.0 \%$ \\
21 to 25 years ago & $0.2 \%$ & $5.7 \%$ & $1.0 \%$ & $0.1 \%$ & $0.0 \%$ & $0.0 \%$ \\
26 to 32 years ago & $0.2 \%$ & $5.2 \%$ & $0.8 \%$ & $0.1 \%$ & $0.0 \%$ & $0.0 \%$ \\
33 or more years ago & $0.3 \%$ & $11.6 \%$ & $0.6 \%$ & $0.1 \%$ & $0.1 \%$ & $0.0 \%$ \\
\hline Total & $2.7 \%$ & $78.2 \%$ & $17.3 \%$ & $0.6 \%$ & $1.1 \%$ & $0.1 \%$ \\
\hline
\end{tabular}

2

5

7

8

9

10

11

12

13

14

15

16

17

18

19

20

21

22

23

24

25

26

27

28

29

30

31

32

33

34

35

36

37

38

39

40

41

42

43

44

45

46

47

48

49

50

51

52

53

54

55

56

57

58

59

60 
Figure 1 Tenure and Dwelling type by generation, Australia

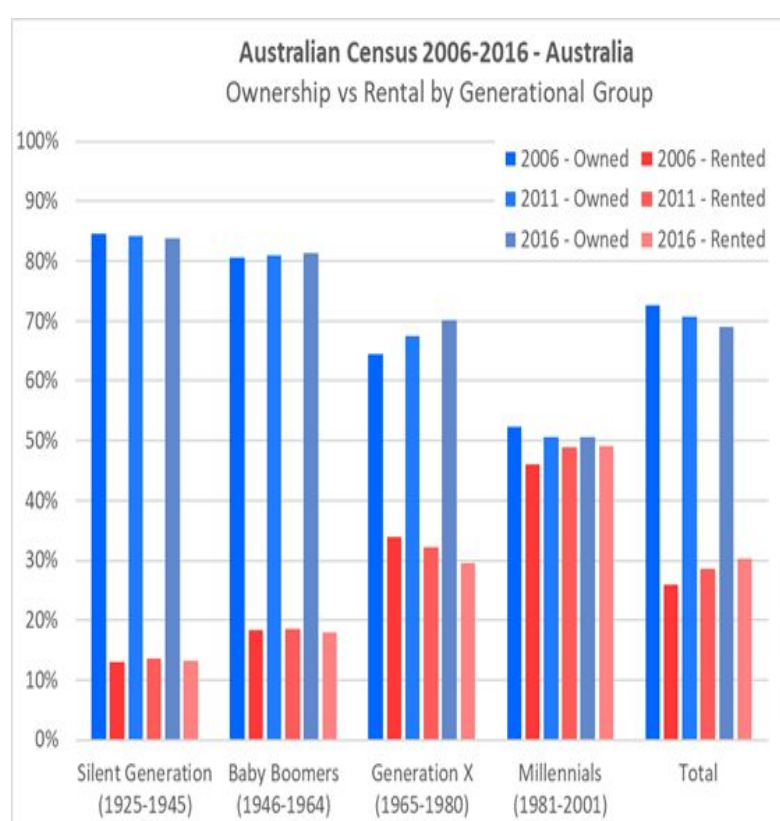

Source: Author Analysis of ABS Data from 2006,2011 and 2016 Census of Population and Housing

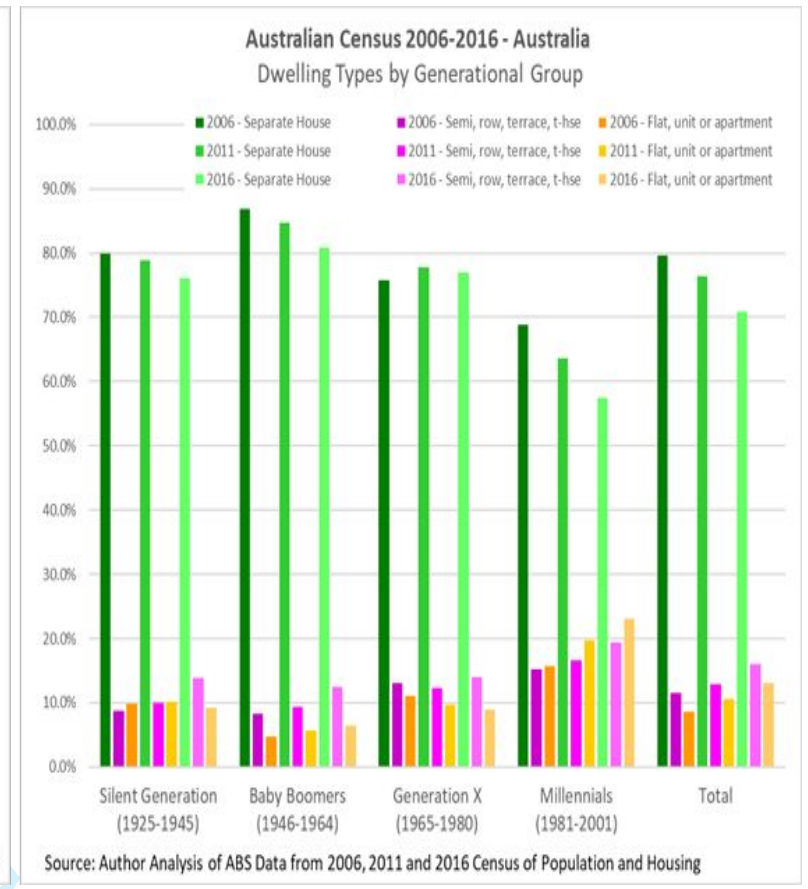


Figure 2 Analysis of tenure at a city level
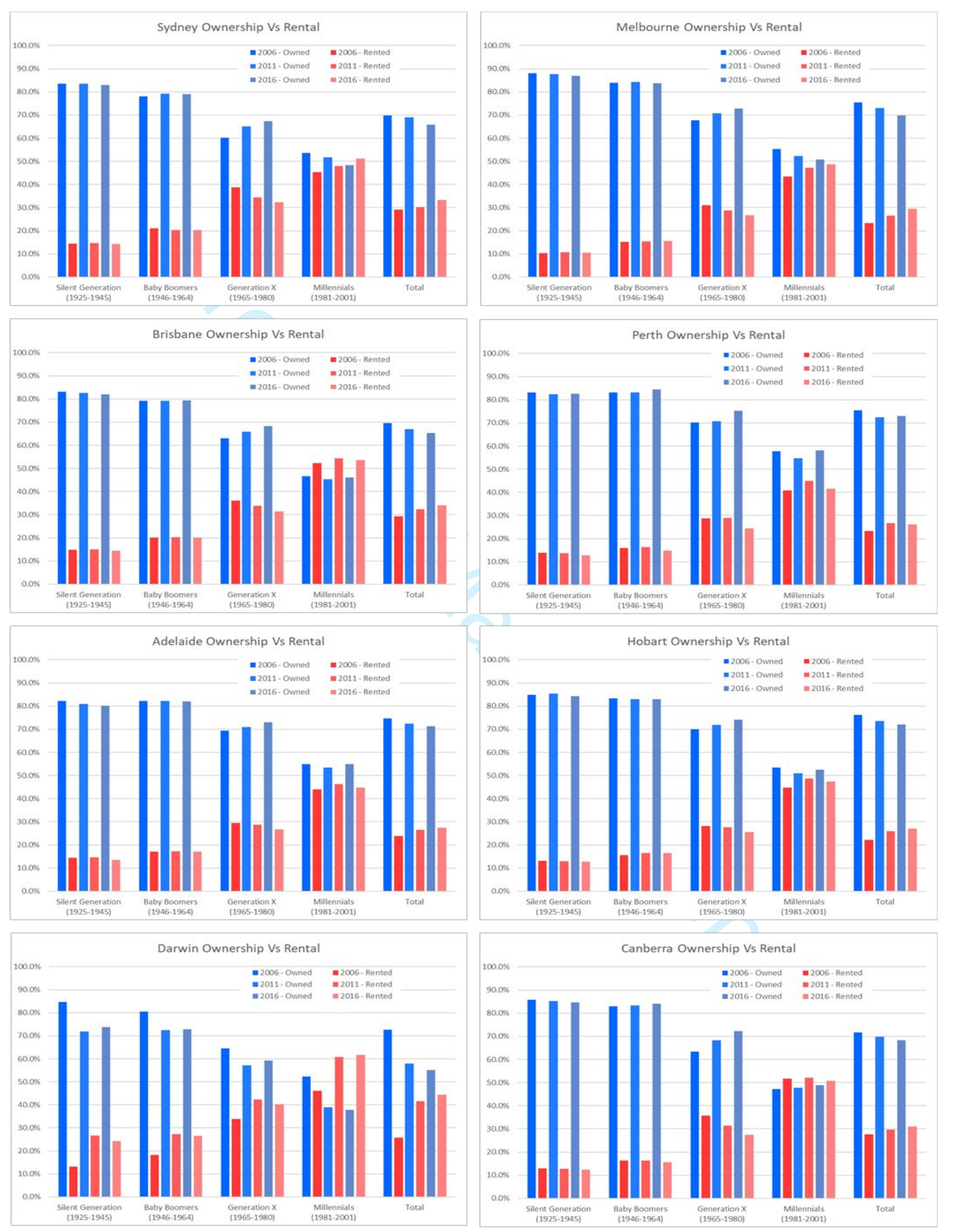

Source: Author Analysis of ABS Data from 2006, 2011 and 2016 Census of Population and Housing 
Figure 3 Analysis of type at a city level
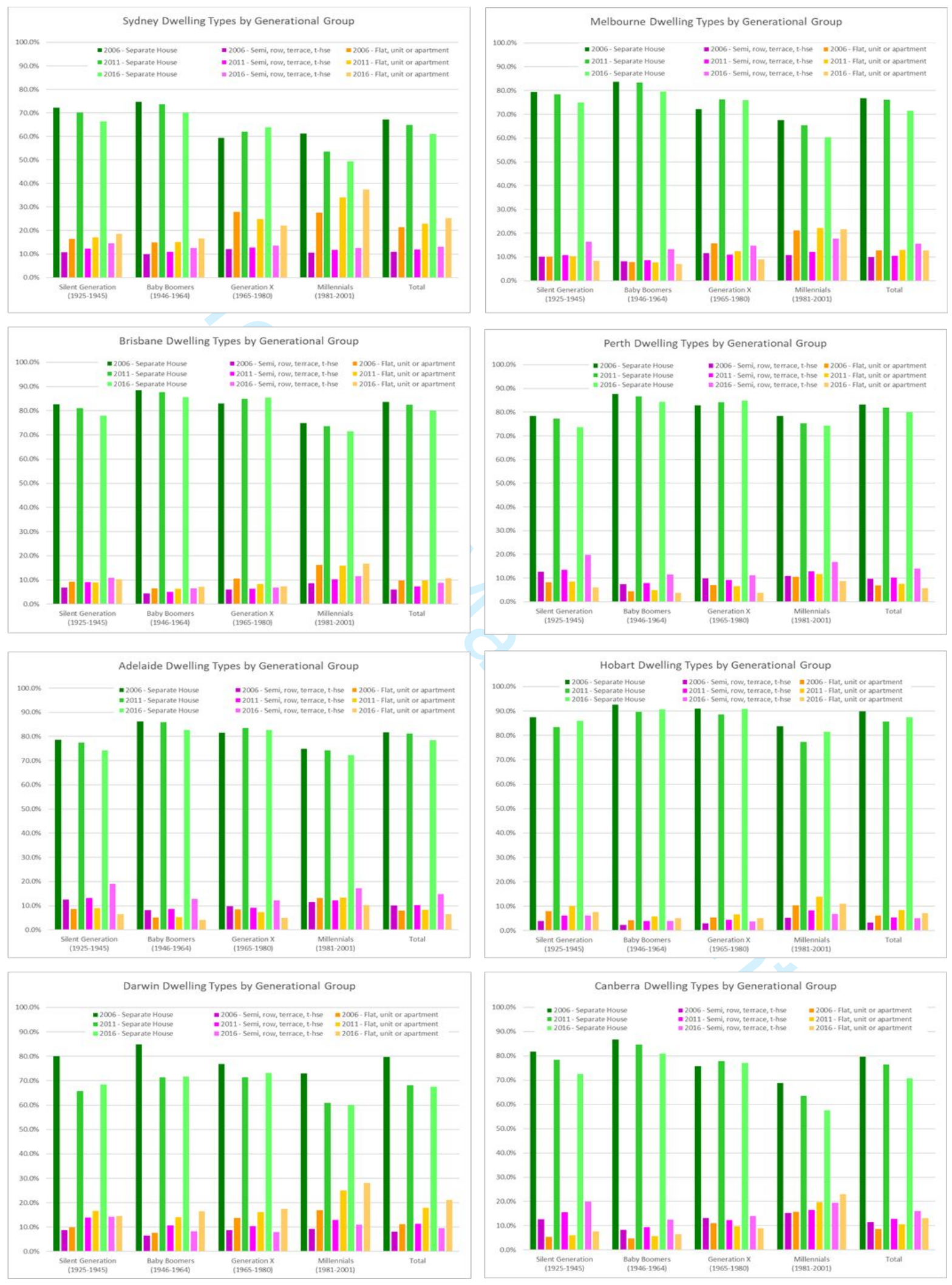

Source: Author Analysis of ABS Data from 2006, 2011 and 2016 Census of Population and Housing 
Figure 4 Transactions in Adelaide: value and site area analysis
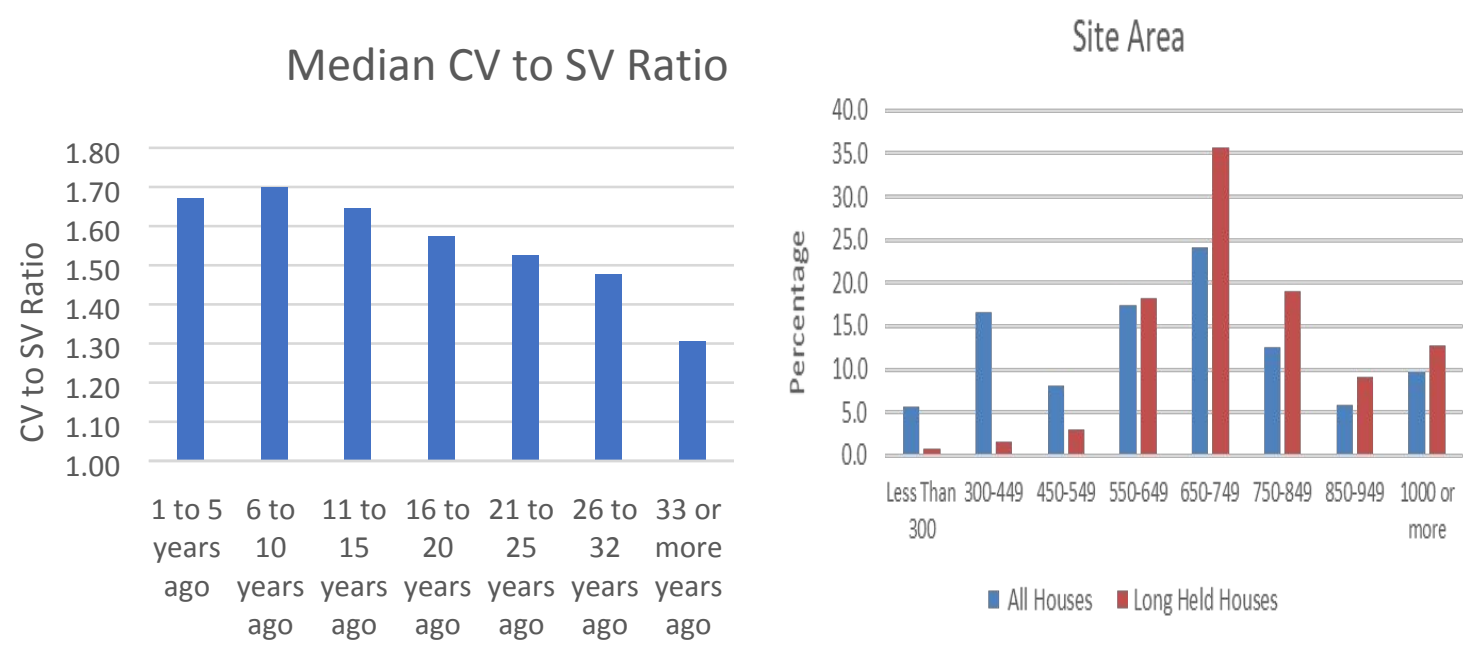
55

56

57

58

59

60 


\section{Locked Out: Generational inequalities of} housing tenure and housing type

Lowies, B

2022-07-12

http://hdl.handle.net/10179/16822

22/04/2023 - Downloaded from MASSEY RESEARCH ONLINE 